\title{
Pengembangan Karier Profesional Perawat Non Pns Di Rumah Sakit X
}

\section{Professional Career Development of Non-Civil Servant Nurses at X Hospital}

\author{
Ahmad Muslim ${ }^{1}$, Sutinah ${ }^{2}$ \\ ${ }^{1}$ Rumah Sakit Universitas Airlangga, Surabaya \\ ${ }^{2}$ Fakultas Ilmu Sosial dan Ilmu Politik, Universitas Airlangga, Surabaya \\ Email : farelotionship@gmail.com; sutinah@fisip.unair.ac.id
}

\begin{abstract}
ABSTRAK
Pengembangan karier yang sesuai dengan kebutuhan dan kompetensi perawat dapat diwujudkan, jika terdapat keseimbangan antara upaya pengembangan karier yang secara individual dilakukan oleh perawat dan upaya pengembangan karier secara organisasional yang dilakukan oleh pihak manajemen rumah sakit. Penelitian ini bertujuan untuk mengetahui gambaran proses pengembangan perawat non PNS di Rumah Sakit X. Jenis penelitian adalah penelitian deskriptif dengan menggunakan metode kualitatif, sehingga dapat menggambarkan secara rinci dan lengkap mengenai pengembangan karier perawat non PNS di Rumah Sakit X. Data diperoleh melalui wawancara terhadap perawat yang masih aktif bekerja dengan status kepegawaian PNS, non PNS, dan perawat yang telah resign dari Rumah Sakit X. Hasil penenlitian ini menunjukkan bahwa Rumah Sakit X menerapkan sistem jenjang karier profesional Perawat Klinis untuk perawat non PNS. Penerapan jenjang karier profesional Perawat Klinis di Rumah Sakit X berdasarkan pendidikan formal dan pendidikan berkelanjutan berbasis kompetensi. Pembagian jenjang karier Perawat Klinis (PK) mulai dari PK I sampai PK V. Pengembangan karier perawat non PNS di Rumah Sakit X saat ini masih berdasarkan karier profesional Perawat Klinis. Saat ini pihak manajamen Rumah Sakit X sedang merencanakan pengembangan karier profesional Perawat Riset.
\end{abstract}

Kata kunci : Pengembangan Karier, Karier Perawat, Rumah Sakit

\begin{abstract}
ABSTRACK
Career development in accordance to the needs and competencies of the nurses can't be achieved unless there is a balance between career development efforts carried individually by the nurses and the one carried organizationally by the hospital management. This research aims to describe the developing process of non-civil servant nurses at $X$ Hospital. The type of this research is a descriptive research by using qualitative method to describe the career development of the non-civil servant nurses at $X$ Hospital in a complete detail. The examined data is obtained through interviews with nurses whom are actively working as civil servants, non-civil servants, and those who have already resigned from $X$ Hospital. The results of this research indicate that $X$ Hospital is implementing a Professional Clinical Nurse Career Path System for the noncivil servant nurses. The enforcement of this career path system at $X$ Hospital is based on the formal education and the competency-based sustainable education. The division of Clinical Nurse (PK) career paths ranging from PK I to PK V. The career development of non-civil servant nurses at $X$ Hospital is currently based on the professional career of Clinical Nurses. Nowadays, the management of $X$ Hospital is planning to impose a professional career development of Research Nurses.
\end{abstract}

Keywords: Career Development, Nurse Career, Hospital 


\section{PENDAHULUAN}

Rumah sakit sebagai penyedia jasa pelayanan kesehatan saat ini sudah berkembang pesat. Jumlah rumah sakit di Indonesia semakin meningkat, tercatat sejak tahun 2012 sampai dengan April 2018 terus mengalami peningkatan setiap tahunnya. Rumah sakit dituntut untuk memberikan pelayanan yang sebaik-baiknya, karena rumah sakit tidak hanya bersaing dengan rumah sakit lainnya tetapi juga bersaing dengan puskesmas, praktik dokter, dan pelayanan kesehatan lainnya. Demi menjaga kualitas pelayanan dan kinerja rumah sakit, pihak manajemen harus mampu mempertahankan Sumber Daya Manusia (SDM) yang dimilikinya.

SDM merupakan aset yang berharga dalam suatu perusahaan atau organisasi seperti rumah sakit. Keberhasilan rumah sakit dalam memberikan jasa pelayanan ditentukan oleh kualitas SDM. Perawat merupakan SDM terbesar di rumah sakit yang memiliki peran penting dalam menjaga dan meningkatkan mutu pelayanan kesehatan di rumah sakit. Di Rumah Sakit X jumlah perawat non Pegawai Negeri Sipil (PNS) sebanyak 227, yaitu 39\% dari total seluruh pegawai non PNS. Perawat bertanggung jawab dalam memberikan pelayanan keperawatan dan memberikan asuhan keperawatan kepada pasien yang sesuai dengan kompetensi dan kewenangan yang dimilikinya. Selain itu, perawat memiliki fungsi interdependen yang merupakan kemampuan menjalin hubungan baik atau tindakan kolaborasi dengan sesama perawat, dokter, maupun tenaga kesehatan lainnya.

Demi menjaga kualitas pelayanan, pihak rumah sakit harus melakukan kegiatan yang berkaitan dengan pengembangan SDM, terutama untuk perawat. Pengembangan SDM sebagai proses dalam meningkatkan kemampuan dan kompetensi pegawai dalam rangka meningkatkan kinerja. Pengembangan SDM merupakan kebutuhan yang mendasar yang harus menjadi prioritas rumah sakit dalam program-programnya, hal ini bertujuan untuk mencapai visi dan misi rumah sakit. Pengembangan SDM akan menambah kemampuan dan kompetensi perawat sesuai dengan keahlian dan potensinya. Nursalam (2014) mengatakan bahwa pengembangan SDM di bidang keperawatan akan lebih mudah jika perawat diberikan kesempatan untuk berkompetensi. Dewan pengurus pusat Persatuan Perawat Nasional Indonesia (PPNI) menyatakan bahwa perawat harus selalu mengembangkan dan meningkatkan kemampuan profesionalnya melalui pendidikan, pelatihan, dan kegiatan ilmiah lainnya.

Pelatihan bagi perawat merupakan kegiatan pendidikan berkelanjutan yang bertujuan untuk meningkatkan kompetensi perawat. Pelatihan merupakan bagian dari 
Ahmad Muslim, Sutinah : Professional Career Development of Non PNS Nurses...

Pendidikan Keperawatan Berkelanjutan (PKB) perawat yang merupakan salah satu syarat untuk kenaikan jenjang profesional perawat. Dalam penyelenggaraan kegiatan pelatihan bagi perawat memiliki standar yang telah ditentukan oleh PPNI, hanya lembaga yang memenuhi kriteria standar yang dapat melaksanakan pelatihan bagi perawat. Dengan bertambahnya kemampuan dan kompetensi perawat dapat dijadikan dasar untuk penentuan karier perawat. Dengan adanya karier akan membuat perawat selalu mengembangkan dan meningkatkan kinerja dan kemampuan profesionalnya.

Pengembangan karier perawat dalam bentuk jenjang karier perawat merupakan sistem untuk menggali potensi sesuai dengan bidang pekerjaan melalui peningkatan kompetensi yang menghasilkan kinerja yang profesional. Adanya sistem jenjang karier akan memberikan kesempatan bagi perawat mengembangkan kompetensinya. Jenjang karier mempunyai makna tingkatan kompetensi untuk melaksanakan asuhan keperawatan sesuai dengan kewenangan klinis yang dimiliki perawat. Oleh karena itu rumah sakit harus memperhatikan pengembangan karier perawat, karena dengan mengabaikan pengembangan karier perawat sama saja dengan mengabaikan pelayanan keperawatan di rumah sakit.

Pengembangan karier merupakan salah satu bentuk penghargaan bagi perawat atas kompetensi dan kinerjanya selama bekerja di rumah sakit. Ketika karier perawat di sebuah rumah sakit tidak berkembang, berarti ada permasalahan serius yang perlu diperhatikan di rumah sakit tersebut. Permasalahan tersebut bisa berasal dari individu yang bersangkutan maupun dari pihak rumah sakit. Rumah sakit perlu harus mempunyai staf keperawatan yang kompeten sesuai dengan misi, sumber daya, dan kebutuhan pasien. Oleh karena itu pihak pimpinan atau manajemen rumah sakit harus menjadikan pengembangan karier sebagai salah satu perhatian serius demi kepentingan dan kemajuan bersama.

Rumah Sakit X merupakan rumah sakit pendidikan yang ditetapkan oleh pemerintah sebagai rumah sakit tipe B pada tahun 2016. Perubahan dari rumah sakit tipe C menjadi tipe B harus diimbangi dengan peningkatan kualitas, baik dari segi pelayanan maupun penunjang medis. Rumah Sakit $\mathrm{X}$ telah terakreditasi paripurna dan baru saja lolos akreditasi rumah sakit berstandar internasional dari Komisi Akreditasi Rumah Sakit (KARS) dengan predikat bintang enam. Dengan demikian di Rumah Sakit X telah melaksanakan pemberlakuan jenjang karier bagi perawat yang memiliki kompetensi khusus, sesuai dengan standar Kompetensi dan Kewenangan Staf (KKS) milik KARS. Penerapan jenjang karier perawat tersebut tidak menghindarkan Rumah Sakit X dari 
turnover intention perawat.

Data persentase turnover perawat di Rumah Sakit X pada tahun 2019 mencapai 14\%. Angka tersebut melebihi standar turnover menurut Leap dalam Lusiati (2013) yang hanya $10-11 \%$ per tahun. Berdasarkan data kuesioner pengunduran diri (resign) dari SDM Rumah Sakit X, terdapat beberapa alasan resign, yaitu diterima berkerja di perusahaan/intansi lain, melanjutkan kuliah/ mendapatkan beasiswa, alasan keluarga/mengikuti suami/istri, dan alasan pribadi/lain-lain. Dari beberapa alasan yang menyebabkan perawat tersebut resign, alasan yang paling banyak adalah alasan karena diterima bekerja di perusahaan/instansi lain. Alasan ini dapat menjadi indikasi bahwa non PNS di Rumah Sakit X merasa tidak ada kejelasan pada karier mereka untuk kedepannya. Oleh karena itu, peniliti tertarik untuk melakukan penelitian mengenai pengembangan karier perawat non PNS di Rumah Sakit X

\section{METODE}

Penelitian ini dilakukan dengan menggunakan metode kualitatif. Jenis penelitian yang digunakan adalah penelitian deskriptif, dimana dalam penelitian ini bertujuan menggambarkan secara rinci dan lengkap mengenai pengembangan karier perawat di Rumah Sakit X. Dalam penelitian ini cara memperoleh data yang akan dipergunakan adalah dengan cara wawancara. Informan dalam penelitian ini adalah perawat yang masih aktif bekerja dengan status kepegawaian PNS, non PNS, dan perawat yang telah resign dari Rumah Sakit X.

Wawancara kepada informan dilakukan secara semiterstruktur (semistructure interview). Jenis wawancara semiterstruktur ini menurut Sugiyono (2016) sudah termasuk dalam kategori in-dept interview, di dalam pelaksanaannya lebih bebas bila dibandingkan dengan wawancara terstruktur. Tujuan dari wawancara jenis ini adalah untuk menemukan permasalahan secara lebih terbuka, di mana pihak yang diajak wawancara diminta pendapat, dan ide-idenya. Dari hasil wawancara informan akan dianalisa sehingga akan memperoleh kesimpulan.

Agar analisa data secara kualitatif ini dapat memperoleh keteraturan dan sistematis, dalam penelitian ini menggunakan teknik analisa data Miles dan Huberman dalam Sugiyono (2016) yang meliputi : 1) reduksi data yang berarti merangkum, memilih hal pokok, memfokuskan pada hal-hal yang penting, dicari tema dan polanya; 2) Penyajian data yang digunakan dalam penelitian ini, dilakukan dalam bentuk uraian teks yang bersifat naratif; 3) Verifikasi dilakukan dengan meninjau ulang data lapangan yang 
Ahmad Muslim, Sutinah : Professional Career Development of Non PNS Nurses...

didukung bukti-bukti yang valid, sehingga kesimpulan yang dikemukakan merupakan kesimpulan yang kredibel.

\section{HASIL}

Rumah Sakit X dibangun dengan tujuan menjadi sarana dalam rangka menunjang aktivitas pendidikan. Sebagai rumah sakit pendidikan, Rumah Sakit X menjadi rumah sakit pendidikan bagi mahasiswa Fakultas Kedokteran dan Ilmu kesehatan lainnya di lingkungan Universitas X. Keberhasilan promosi Rumah Sakit X dan simulasi pelayanan pasien yang hasilnya cukup memuaskan membuat Rumah Sakit X memperoleh ijin membuka layanan kesehatan bagi masyarakat sejak tahun 2011. Rumah Sakit X mempunyai tugas memberikan pelayanan kesehatan secara paripurna, efektif, dan efisien dengan mengutamakan upaya pencegahan, penyembuhan, pemulihan, dan rujukan yang dilaksanakan secara serasi, serta terintegrasi dengan kegiatan tugas pendidikan dan penelitian.

Pelayanan di Rumah Sakit X semakin bertambah sesuai dengan kenaikan kelas rumah sakit dari Rumah Sakit tipe C menjadi tipe B pada tahun 2016. Kenaikan Rumah Sakit $\mathrm{X}$ menjadi tipe $\mathrm{B}$ berarti harus dimbangi dengan peningkatan fasilitas sarana prasarana dan kualitas pelayanan. Hal ini akan semakin menumbuhkan kepercayaan masyarakat terhadap Rumah Sakit X. Jenis pelayanan yang sudah tersedia pada Rumah Sakit X adalah pelayanan Instalasi Gawat Darurat, Instalasi Rawat Inap, Instalasi Rawat Jalan, Instalasi Hemodialisis, Intensive Care Unit, Medical Check Up, Laboratorium, Radiologi, Catheterization Laboratory, Rehabilitasi Medik, Farmasi.

Peningkatan fasilitas sarana prasarana dan kualitas pelayanan di Rumah Sakit X diimbangani dengan peningkatan kualitas dan kuantitas tenaga kesahatan, salah satunya yaitu perawat. Hal ini dibuktikan dengan bertambahnya jumlah perawat non PNS di Rumah Sakit Sakit X setiap tahunnya, dengan rincian sebagai berikut :

Tabel 1. Jumlah Perawat di Rumah Sakit X Dari Tahun 2016 - 2019

\begin{tabular}{cc}
\hline Tahun & Jumlah Perawat Non PNS \\
\hline 2016 & 140 \\
2017 & 163 \\
2018 & 200 \\
2019 & 235 \\
\hline
\end{tabular}

Sumber : Data SDM Rumah Sakit X 
Dari jumlah perawat non PNS pada tahun 2019 tersebut, perawat yang memiliki pendidikan D-III sebanyak 61 orang (27\%) dan pendidikan D4/S1 profesi ners sebanyak 166 orang (73\%). Peraturan Menteri Kesehatan (PMK) nomor 40 tahun 2017 menyatakan bahwa persyaratan sistem jenjang karier profesional perawat adalah memiliki latar belakang pendidikan minimal D-III. Hal ini menunjukkan bahwa latar belakang pendidikan perawat non PNS di Rumah Sakit X telah memenuhi syarat untuk memiliki jenjang karier profesional.

Hasil wawancara dengan informan menunjukkan bahwa karier perawat non PNS di Rumah Sakit X masih belum memiliki kejelasan hingga saat ini. Hal ini dibuktikan dengan belum adanya perencanaan karier untuk perawat non PNS secara struktural di Rumah Sakit X. Pilihan jenjang karier untuk pegawai tidak selalu bergerak keatas secara vertikal, sesuai dengan pendapat Usmara (2007) bahwa pilihan jalur pengembangan karier meliputi enrichment, lateral, vertical, relocation, exploration, realignment. Meskipun belum terdapat peraturan yang mengatur karier perawat non PNS secara struktural, namun Rumah Sakit X telah menerapkan sistem jenjang karier profesional Perawat Klinis (PK), hal ini sesuai dengan PMK nomor 40 tahun 2017. Karier profesional Perawat Klinis ini dapat menjadi jalur karier bagi perawat non PNS, karena jalur karier merupakan pilihan arah karier seseorang untuk mengembangkan kariernya. Perawat Klinis merupakan perawat yang memberikan asuhan keperawatan langsung kepada pasien sebagai individu, keluarga, kelompok dan masyarakat, dengan kata lain Perawat Klinis ini merupakan perawat yang langsung menangani pasien atau perawat pelaksana di rumah sakit.

Peningkatan jenjang karier profesional Perawat Klinis ini diperoleh melalui pendidikan formal dan pendidikan berkelanjutan berbasis kompetensi (sertifikasi), serta pengakuan terhadap kemampuan yang didasarkan pada pengalaman kerja dan kinerja praktik keperawatan. Perawat Klinis memiliki jenjang berdasarkan pendidikan formal maupun pendidikan berkelanjutan (sertifikasi), dengan jenjang mulai dari PK I sampai PK V. Dalam penentuan tingkatan PK, pihak Rumah Sakit X melakukan proses kredensial dengan melakukan verifikasi terhadap dokumen staf keperawatan (pendidikan, registrasi, izin praktik, kewenangan klinis, pelatihan, pengalaman, dan evaluasi kinerja profesional). Berikut ini rincian jenjang Perawat Klinis non PNS di Rumah Sakit X : 
Ahmad Muslim, Sutinah : Professional Career Development of Non PNS Nurses...

Tabel 2. Rincian Perawat Klinis Non PNS di Rumah Sakit X Tahun 2019

\begin{tabular}{cc}
\hline Perawat Klinis & Jumlah Perawat \\
\hline Pra PK & 13 \\
PK I & 149 \\
PK II & 62 \\
PK III & 11 \\
PK IV & - \\
PK V & - \\
\hline
\end{tabular}

Sumber : Data SDM Rumah Sakit X

Berdasarkan Tabel 2 menunjukkan bahwa di Rumah Sakit X belum ada perawat non PNS pada posisi PK IV dan V, sedangkan jumlah terbesar ada di posisi PK I. Pengembangan layanan di Rumah sakit X dan tingginya angka turnover perawat non PNS di Rumah Sakit X yang tinggi yang menjadi faktor penyebab perawat non PNS banyak di posisi PK I. Angka turnover perawat non PNS yang tinggi merupakan hal yang merugikan bagi rumah sakit $\mathrm{X}$. Mencari perawat pengganti yang tepat bukanlah hal yang mudah, dan dalam proses rekrutmen juga membutuhkan biaya. Disisi lain, turnover dapat memberikan manfaat seperti lebih besar kesempatan untuk promosi bagi perawat. Promosi jabatan merupakan salah satu bentuk penghargaan yang diberikan kepada perawat atas pencapaian kinerjanya, namun hal ini belum diterapkan untuk perawat non PNS di Rumah Sakit X. Belum diterapkannya jenjang karier seperti promosi jabatan untuk perawat non PNS ini menjadi salah satu alasan untuk resign.

Perlu dilakukan perubahan sistem karier bagi perawat non PNS di Rumah Sakit $\mathrm{X}$, salah satunya bisa dilakukan melalui pengembangan karier. Menurut Sulistiyani (2015) pengembangan karier memiliki manfaat diantaranya, untuk motivasi pegawai agar dapat berkembang, mengurangi subyektivitas dalam promosi, dan sebagai sarana untuk memperoleh pegawai yang cakap dan terampil dalam melaksanakan pekerjaan. Bisa dikatakan perawat non PNS di Rumah Sakit X belum memiliki jenjang karier yang jelas. Belum adanya jenjang karier bagi pegawai tidak tetap dikarenakan hal tersebut belum diatur dalam Hospital Bylaws (HBL) atau Peraturan Internal Rumah Sakit X. Jenjang karier akan memberikan dampak positif bagi perawat, hal ini sesuai dengan pendapat Kolibu (2015) bahwa dengan adanya sistem jenjang karier dapat merubah moral perawat lewat kepuasan kerja dari pekerjaan yang dia lakukan dan akan mendorong perawat untuk terus meningkatkan pengetahuan dan keahliannya sesuai dengan bidangnya. 


\section{PEMBAHASAN}

Perencanaan dan pengembangan karier bagi perawat non PNS merupakan tugas yang harus dipikirkan oleh pimpinan Rumah Sakit X. Sehingga perawat non PNS tidak disibukkan oleh masalah karier, agar mereka lebih fokus pada pekerjaan dan menentukan pilihan karier mereka masing-masing. Meskipun terdapat pengembangan karier secara individual namun harus diimbangi dengan pengembangan karier secara organisasional. Sesuai dengan pendapat Sulistiyani (2015) bahwa pengembangan karier dalam organisasi membutuhkan rencana pegawai dalam mewujudkan kariernya sendiri dan perencanaan program karier yang di desain oleh organisasi. Proses tersebut merupakan usaha yang terorganisir dan terencana untuk mencapai keseimbangan antara keinginan karier individu dengan perencanaan karier yang telah dibuat oleh pihak Rumah Sakit X.

Rumah Sakit $\mathrm{X}$ memiliki program pelatihan dan peningkatan kompetensi pegawai, program ini bertujuan untuk meningkatkan kemampuan dan kompetensi seluruh pegawai Rumah Sakit X. Menurut Samsudin (2010) bahwa setiap orang harus siap mengembangkan diri untuk kariernya, oleh karena itu setiap pegawai harus diberikan kesempatan untuk berkembang, misalnya melalui program pelatihan, pengambilan kursus atau penambahan gelar. Program pelatihan pegawai di Rumah Sakit X ini telah dilaksanakan, namun dalam pelaksanaannya dinilai belum konsiten dan belum merata diberikan kepada seluruh pegawai.

Pemberian pelatihan kepada pegawai, khususnya perawat yang belum merata tersebut dikarenakan sebelumnya memang belum ada peraturan yang jelas yang mengatur tentang pemberian pelatihan. Berdasarkan data dari bagian Pendidikan dan Penelitian (Diklit) Rumah Sakit X, saat ini peraturan untuk pemberian pelatihan kepada pegawai sudah ada. Dalam pemberian pelatihan memang tidak dapat sekaligus seluruh, pelatihan kepada pegawai diberikan secara bertahap dan bergantian. Peraturan tentang pelatihan ini harus disosialisasikan kepada seluruh pegawai, agar mereka mengerti bahwa setiap pegawai berhak memperoleh pelatihan. Dengan adanya peraturan tentang pelatihan untuk pegawai ini menunjukkan bahwa Rumah Sakit X memperhatikan karier pegawai. Pendidikan dan pelatihan akan meningkatkan kemampuan intelektual dan keterampilan pegawai yang dapat disumbangkan pada organisasi (Samsudin, 2010).

Program pelatihan bagi perawat non PNS di Rumah Sakit X telah memberikan manfaat bagi mereka. Melalui pelatihan dapat menambah kompetensi perawat dan dapat membuat perawat bekerja lebih baik, serta dapat dijadikan dalam syarat penetapan jenjang Perawat Klinis. Peningkatan jenjang karier Perawat Klinis di Rumah Sakit X 
Ahmad Muslim, Sutinah : Professional Career Development of Non PNS Nurses...

belum diimbangi dengan peningkatan kesejahteraan perawat non PNS. Hal ini terjadi karena sistem remunerasi perawat non PNS di Rumah Sakit X dibedakan bukan berdasarkan tingkat jenjang karier profesional perawat, namun dibedakan berdasarkan ruangan tempat perawat tersebut ditugaskan. Azwir (2010) berpendapat bahwa peningkatan jenjang karier perawat selalu diikuti dengan adanya penghargaan (remunerasi) baik penghargaan berupa pendidikan berkelanjutan atau yang berhubungan dengan peningkatan pendapatan. Peningkatan pendapatan perawat harus didasarkan pada pencapaian keberhasilan dari kompetensinya.

Pengembangan karier itu tidak hanya masalah pegawai diberi pelatihan dan pihak rumah sakit memberikan fasilitas kepada pegawainya untuk berkarier, tapi juga masalah kesejahteraan pegawai. Oleh karena itu pihak Rumah Sakit X harus lebih memperhatikan kesejahteraan perawat, hal ini perlu dilakukan untuk meningkatkan loyalitas perawat terhadap rumah sakit Sesuai dengan pendapat Dubrin dalam Mangkunegara (2011) bahwa salah satu tujuan pengembangan karier itu untuk kesejahteraan pegawai, perusahaan merencanakan karier pegawai dengan cara meningkatkan kesejahteraan pegawai, agar pegawai lebih tinggi loyalitasnya.

Jenjang karier profesional perawat merupakan sebuah sistem untuk meningkatkan kinerja dan profesionalisme perawat, melalui peningkatan kompetensi. Peningkatan kompetensi perawat diperoleh dari pendidikan formal berjenjang, pendidikan informal yang sesuai, dan pengalaman praktik klinis yang diakui. Di dalam PMK nomor 40 tahun 2017 disebutkan bahwa pengembangan sistem jenjang karier profesional bagi perawat dapat dibedakan antara tugas pekerjaan (job) dan karier (career). Pekerjaan diartikan sebagai suatu posisi atau jabatan yang diberikan, serta ada keterikatan hubungan pertanggungjawaban dan kewenangan antara atasan dan bawahan, dan mendapatkan imbalan penghargaan berupa uang. Karier diartikan sebagai suatu bidang kerja yang dipilih dan ditekuni oleh individu untuk dapat memenuhi kepuasan kerja individu melalui suatu sistem dan mekanisme peringkat dan bertujuan untuk meningkatkan kinerja, sehingga akan memberikan kontribusi terhadap bidang profesi yang dipilihnya.

Rumah Sakit X memberikan kesempatan kepada perawat untuk memilih kariernya masing-masing sesuai dengan kompetensi. Pilihan karier perawat ini dilakukan dengan cara menigisi form bidang keperawatan yang diminati oleh masing-masing perawat. Saat ini beberapa perawat telah di rotasi ke unit kerja yang sesuai dengan kompetensi dan peminatan yang telah mereka pilih. Namun hal ini belum bisa diterapkan secara keseluruhan, dikarenakan menyesuaikan dengan keadaan dan kebutuhan Rumah 
Sakit X. Penerapan program ini diharapkan agar perawat mampu meningkatkan kinerja dan motivasi untuk bekerja sesuai dengan karier yang telah dipilihnya.

Pengembangan karier profesional perawat mendorong perawat menjadi perawat profesional yang diharapkan mampu berpikir rasional, mengakomodasi kondisi lingkungan, mengenal diri sendiri, belajar dari pengalaman dan mempunyai aktualisasi diri sehingga dapat meningkatkan jenjang karier profesinya. Menurut PMK nomor 40 tahun 2017 jenjang karier profesional di Indonesia terdiri dari 4 bidang, meliputi Perawat Klinis (PK), Perawat Manajer (PM), Perawat Pendidik (PP) dan Perawat Peneliti/Riset (PR). Keempat jalur jenjang karier profesional perawat digambarkan sebagai berikut :

Bagan 1. Pola Penjenjangan Karier Profesional Perawat

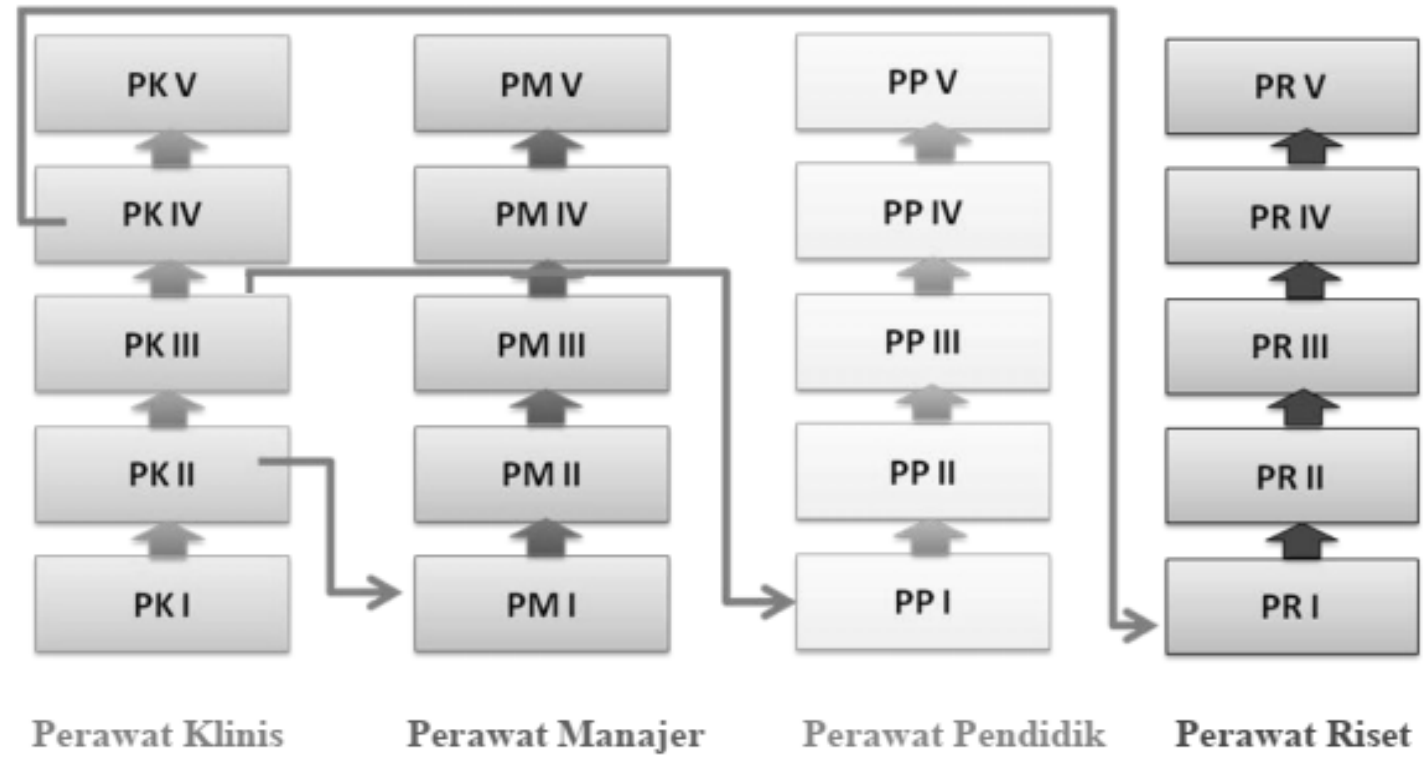

Sumber : Data Kementerian Kesehatan Repulik Indonesia

Di Rumah Sakit X saat ini hanya terdapat jenjang karier profesional Perawat Klinis. Rumah Sakit X merupakan rumah sakit pendidikan, yang seharusnya bisa menerapkan jenjang karier profesional Perawat Pendidik dan Perawat Riset untuk perawat non PNS. Dengan diterapkannya pola jenjang perawat profesional Perawat Pendidik dan Perawat Riset akan membuka peluang bagi perawat non PNS untuk berkarier di Rumah Sakit X. Hal ini menjadi tantangan bagi pihak manajemen Rumah Sakit X dalam pengembangan SDM terutama bagi perawat non PNS. Penerapan jenjang perawat profesional Perawat Pendidik dan Perawat Riset dapat menjadi upaya untuk mengurangi turnover perawat non PNS. Pilihan karier bagi perawat ditambahkan pilihan untuk menjadi Perawat Pendidik dan Perawat Riset, dengan syarat kualifikasi perawat 
Ahmad Muslim, Sutinah : Professional Career Development of Non PNS Nurses...

sesuai dengan PMK nomor 40 tahun 2017. Dalam sistem jenjang karier profesional perawat ini, perawat harus memiliki kemauan dan kemampuan untuk meningkatkan pengetahuan dan ketrampilan sesuai dengan pilihan kariernya.

\section{SIMPULAN}

Perawat non PNS di Rumah Sakit X saat ini belum memiliki jenjang karier yang jelas secara struktural, karena untuk posisi jabatan struktural hanya diduduki oleh perawat PNS. Perawat non PNS sebenarnya bisa saja memiliki jenjang karier, jika pimpinan Rumah Sakit X mau membuat sistem jenjang karier secara struktural untuk perawat non PNS. Hal ini terjadi karena di dalam HBL Rumah Sakit X belum mengatur tentang karier struktural Perawat non PNS. Jenjang karier yang dimiliki perawat non PNS adalah jenjang karier profesional Perawat Klinis.Pengembangan karier Perawat non PNS yang telah dilakukan oleh Rumah Sakit X adalah program pelatihan bagi Perawat non PNS. Upaya yang lainnya yang dilakukan oleh pihak Rumah Sakit X adalah perawat non PNS diberikan kesempatan untuk memilih karier sesuai dengan bidang yang diminati, namun saat ini masih belum dapat dilaksanakan secara keseluruhan. Rumah Sakit X telah berencana untuk mengembangkan jenjang karier profesional perawat untuk Perawat Riset, namun jenjang karier ini masih dikhususkan untuk perawat yang memiliki pendidikan minimal S2 Keperawatan. Rumah Sakit X terus berupaya untuk melakukan perbaikan sistem pengembangan karier perawat non PNS agar lebih baik kedepannya.

\section{UCAPAN TERIMA KASIH}

Ucapan terima kasih penulis haturkan kepada semua pihak yang membantu terlaksananya penelitian ini terutama kepada Rumah Sakit Universitas Airlangga dan Universitas Airlangga Surabaya.

\section{DAFTAR PUSTAKA}

Azwir, Ayuningtyas, D. (2010). Pengembangan Pola Karir Perawat Klinik Rumah Sakit Umum Daerah Tarakan Jakarta Pusat Tahun 2008. Jurnal Manajemen Pelayanan Kesehatan, 13(01), 16-22.

Kornela Kolibu, F., Hariyanto, T., \& Pusparahaju, A. (2014). Pengembangan Model Jenjang Karir Perawat Klinis di Unit Rawat Inap Rumah Sakit. Jurnal Kedokteran Brawijaya, 28(1), 59-64. https://doi.org/10.21776/ub.jkb.2014.028.01.24. 
Lusiati, A \& Supriyanto, S. (2013). Dampak Faktor Individu, Faktor Pekerjaan dan Faktor Organisasi pada Kepuasan Kerja dan Intensi Turnover Perawat. Jurnal Administrasi Kesehatan Indonesia. vol. 1, issue 2 (2013) pp. 156-166.

Mangkunegara, P. (2011). Manajemen Sumber Daya Manusia Perusahaan. Bandung. PT. Remaja Rosda Karya.

Nursalam. (2014). Manajemen keperawatan aplikasi dalam praktik keperawatan profesional. Jakarta: Salemba Medika.

Priharjo, R. (2008). Konsep dan Perspektif Praktik Keperawatan Profesional. Jakarta: EGC.

Ratanto, R., Mustikasari, M., \& Kuntarti, K. (2013). Pengembangan Karir Sebagai Faktor Paling Mempengaruhi Kinerja Perawat Pelaksana. Jurnal Keperawatan Indonesia, 16(2), 114-119. https://doi.org/10.7454/jki.v16i2.10.

Samsudin, Sadili. (2010). Manajemen Sumber Daya Manusia. Bandung: CV. Pustaka Setia.

Sugiyono, P. (2016). Metode Penelitian Kuantitatif, Kualitatif, dan R \& D. Bandung: CV. Alfabeta.

Sulistiyani, A. dan Rosidah. (2015). Manajemen Sumber Daya Manusia: Konsep, Teori dan Pengembangan Dalam Konteks Organisasi Publik. Yogyakarta: Graha Ilmu.

Sunarsih, S., Ilyas, H., \& Nurhayati K, N. K. (2018). Pengembangan Karier dan Kepuasan Kerjaperawat: Studi pada Salah Satu Rumah Sakit di Kabupaten Pringsewu. Jurnal Ilmiah Keperawatan Sai Betik, 14(1), 68. https://doi.org/10.26630/jkep.v14i1.1010.

Usmara, A. (2007). Paradigma Baru Manajemen Sumber Daya Manusia. Jogjakarta: Amara Book.

Wahju Hardjanti, I., Ika Faramita, N., \& Hartojo, H. (2016). Pengembangan Jenjang Karir sebagai Strategi Mengelola Ketidakpuasan Kerja Perawat di Rumah Sakit. Jurnal Kedokteran Brawijaya, 29(3), 285-290. https://doi.org/10.21776/ub.jkb.2016.029.03.9.

Keputusan Dewan Pengurus Pusat Persatuan Perawat Nasional Indonesia Nomor: 017F/DPP.PPNI/SK/K/S/II/2016 Tentang Perubahan Pedoman Pengembangan Keprofesian Berkelanjutan Perawat Indonesia.

Peraturan Menteri Kesehatan Republik Indonesia Nomor 40 Tahun 2017 Tentang Pengembangan Jenjang Karir Profesional Perawat Klinis.

\begin{tabular}{|l|l|}
\hline Submission & 13 November 2019 \\
\hline Review & 03 Desember 2019 \\
\hline Accept & 16 April 2020 \\
\hline Publish & 22 April 2020 \\
\hline DOI & $10.29241 /$ jmk.v\%vi\%i.262 \\
\hline Sinta Level & 4 (Empat) \\
\hline
\end{tabular}

